\title{
Archaeological and Geophysical Investigation and 3D Visualization at the Jánský Vrch Castle in Javorník (Czech Republic)
}

\author{
Hana Dehnerováa ${ }^{\mathrm{a}}$ Jan Martínek ${ }^{\mathrm{b}}$, Martin Moník ${ }^{\mathrm{c}^{*}}$, Pavel Šlézar ${ }^{\mathrm{a}}$ \\ ${ }^{a}$ National Heritage Institute, Horní náměstí 25, 77111 Olomouc, Czech Republic \\ ${ }^{b}$ Transport Research Centre, Research institute, Branch office Olomouc, Wellnerova 3, 77900 Olomouc, Czech Republic \\ 'Department of Geology, Faculty of Science, Palacky University, 17. listopadu 12, 771 46, Olomouc, Czech Republic
}

\section{ARTICLE INFO}

\section{Article history:}

Received: $1^{\text {st }}$ December 2014

Accepted: $2^{\text {nd }}$ June 2015

\section{Keywords:}

Middle Ages

castle

Silesia

ERT

GPR

3D laser scanning

\begin{abstract}
$A B S T R A C T$
An archaeological investigation realized between 2002 and 2012 has re-interpreted the construction phases and spatial organization of the Javorník Castle in Czech Silesia. Its first phase, dating to the beginning of the $14^{\text {th }}$ century, consisted of a bergfried-type castle with a rounded fortification ditch. This fortification was re-built at the end of the $15^{\text {th }}$ and start of the $16^{\text {th }}$ centuries when the castle was divided into upper and lower portions. The Modern Age has seen a complex of constructions at the glacis, pictured also in historical vedutas. Between 2013 and 2014, certain data acquired earlier by archaeological prospecting and excavations were corroborated by electric resistivity tomography (ERT) and ground penetrating radar measurement (GPR); moreover an advanced siege fortification, probably related to a Hussite siege of the castle, was identified by $3 \mathrm{D}$ laser scanning south of the castle.
\end{abstract}

\section{Introduction}

The Jánský Vrch chateau, originally a gothic castle, is a dominant feature of Javorník town (Jeseník district, Olomouc region, Czech Republic; Figure 1). It was built on a rock spur reaching from the Rychlebské hory Mountains into the Vidnava Lowland. This elevated point controls the area to the north, east and south-east; also visible from the spur are the Polish towns of Paczków and Otmuchów. New pieces of knowledge were acquired between 2002 and 2006 by archaeological excavation and supplemented by geophysical prospecting in 2013 and 2014 that verified the position and nature of castle's historical fortifications and buildings. This prospecting was accompanied in 2013 by 3D laser scanning at the glacis south of the castle where two structures of unknown origin, probably for fortification, had also been identified (Anonymous 1934).

*Corresponding author. E-mail: martin.monik@gmail.com

\subsection{History of the Javorník castle/chateaux}

In the course of the second half of the $13^{\text {th }}$ century, Javorník village, along with a stronghold and the St. Cross church, was founded in the lowland around Javorník Creek in Silesia. This took place during the course of the High Middle Ages colonization process directed by Otmuchów castle, though influenced, however, by the long-lasting territorial conflicts between the diocese and the princes of Wrocław. The first written record of the village comes from the register of assets of the Wrocław diocese from 1290. The aforementioned stronghold was erected at the strategic crossroads of roads connecting Moravia and Silesia and remained in function until the first half of the $15^{\text {th }}$ century, when it was probably destroyed as the Hussites moved towards the principality of Nisa (Brachtl, Dohnal 1992).

Historical records indicate that Javorník village was commanded around the end of the $13^{\text {th }}$ and start of the $14^{\text {th }}$ centuries by the duke Bolko I of Svídnice who had a castle built to control both land border and roads connecting the Kłodzko Lowland with the Nisa watershed. In a 


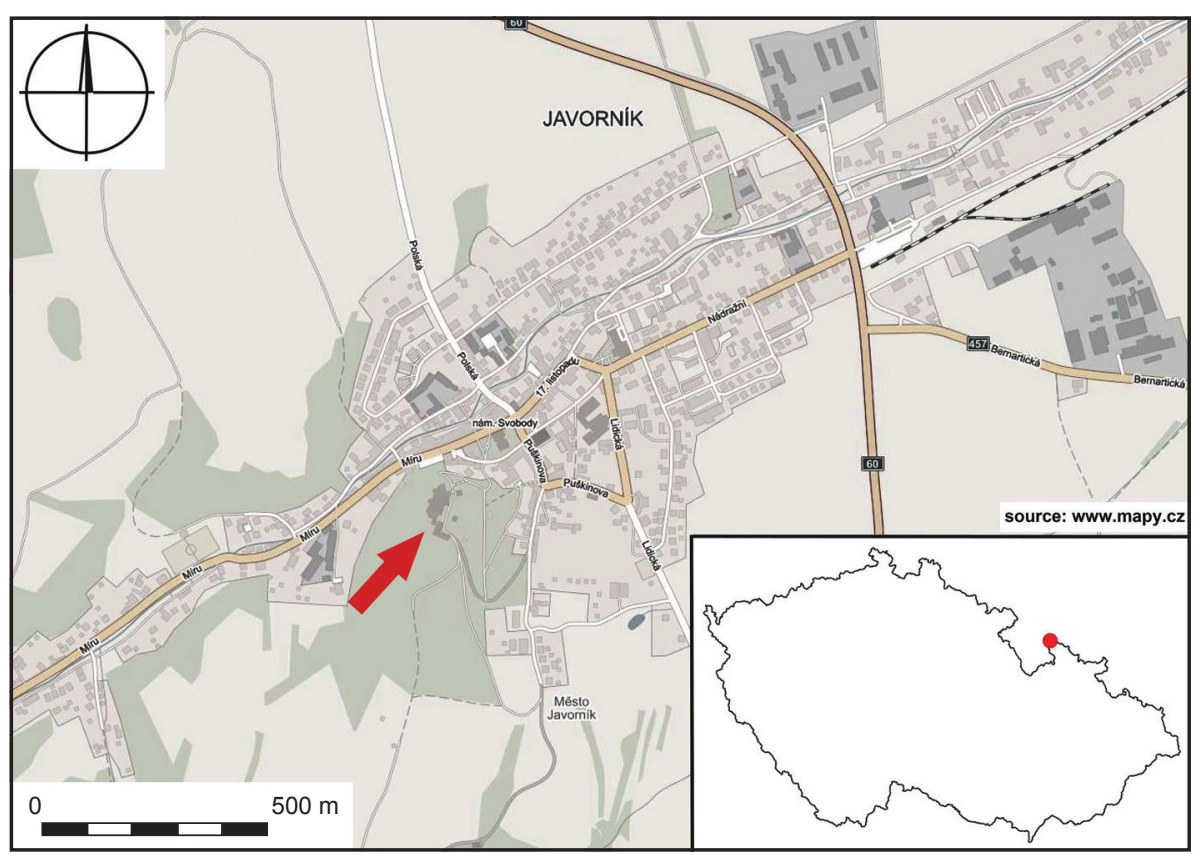

Figure 1. Location of Jánský Vrch castle (arrow) in Javorník.

document from 1307, a castle manager is already mentioned (Kouřil et al. 2000). After 1348, duke Bolek II of Svídnice left his part of Javorník to the Bishop Przeclav of Pogarel and the castle became the property of the Wrocław diocese. Between 1428 and 1432, the castle was taken and occupied by the Hussites and partially destroyed after their departure (for details see Kouřil et al. 2000).

The actual appearance of the castle is due to several reconstructions which took place mainly at the end of the $15^{\text {th }}$, and then the beginning of the $16^{\text {th }}$, and during the course of the $18^{\text {th }}$ century. The bishops Jan Roth and Jan Thurzo had the castle, now called Jánský Vrch (Johannisberg), rebuilt between the 1480s and 1509 into a Late Gothic castle. Later Baroque reconstruction took place during the episcopacy of Filip Gothard Schaffgotsch and a Classicist stairway was constructed around the 1890s/1900s (the building's construction history has been covered by Vítek 2000).

\subsection{Overview of archaeological knowledge}

Archaeological finds were made at the site already in the 1930s but a systematic investigation only took place after 1990 in relation to construction history research of the chateaux (e.g. Brachtl 1998; 2000). An archaeological salvage excavation took place in 2001 and 2002 along with some sewer reconstruction at the eastern glacis (Figure 2; in greater detail in Dehnerová, Šlézar 2013).

An up-to-date archaeological investigation has revealed that the oldest activities at the castle date from the $14^{\text {th }}$ century, which is in accordance with its supposed foundation at the beginning of the $14^{\text {th }}$ century. In the first phase $\left(14^{\text {th }}-15^{\text {th }}\right.$ century), a castle of a bergfried type was built, fortified by a curved ditch (for more details see Dehnerová, Šlézar, in press). In the northern part of the eastern glacis, outside of the ditch, buildings connected with the defence of the castle's entrance have also been identified (Figures 2 and 7). A stone building had stood here, a part of which was unearthed close to the north-eastern corner of the castle (Figure 7), and to the north there had stood another wooden and earthen construction as indicated by a fire destruction layer there.

Significant activities from the period of the castle's reconstruction around 1500 were also identified. The fortification ditch had been filled with the debris of destroyed buildings from around the bergfried, and the terrain, including the ditch, was covered by a mortar layer. From out of the ditch, pottery from the end of the $15^{\text {th }}$ and start of the $16^{\text {th }}$ century was acquired. A new fortification 1.4 metres wide was built later, identified by excavations made in two places (Figures 2 and 7) - in the northern part close to the entrance gate and in the south close to the Classicist house where it had been supported by a tower (overbuilt later by a Modern Age wall). During this period, construction modifications also took place of the gate building and its vicinity.

In the Modern Age $\left(16^{\text {th }}-18^{\text {th }}\right.$ century), the area of the eastern glacis was paved over several times, levelled by further landfills and partially overbuilt by buildings as indicated by both archaeological investigations and iconographic sources from the $18^{\text {th }}$ century.

After 2002, two major construction works took place in the castle area, both related to public utilities' construction. The related trenches actually confirmed the knowledge acquired by earlier investigation. They cut into the layers of Modern Age landfills: in several places remnants of cobble pavements at a depth of 1.3 metres were identified. The rock bed, formed here by amphibolites and gneisses of the Orlice-Sněžník unit (Žáček 1995), was evidenced just exceptionally in the farmyard (Figure 7). The oldest identified pottery dates from the $14^{\text {th }}-15^{\text {th }}$ centuries, but comes from secondary contexts. A number of walls were identified as well, namely in the northern part of the glacis where a foundation stone wall $5.15 \mathrm{~m}$ in length and $1.2 \mathrm{~m}$ 
Figure 2. Javorník, Jánský Vrch overview of archaeological activities in the castle area from 1995 to 2012 .

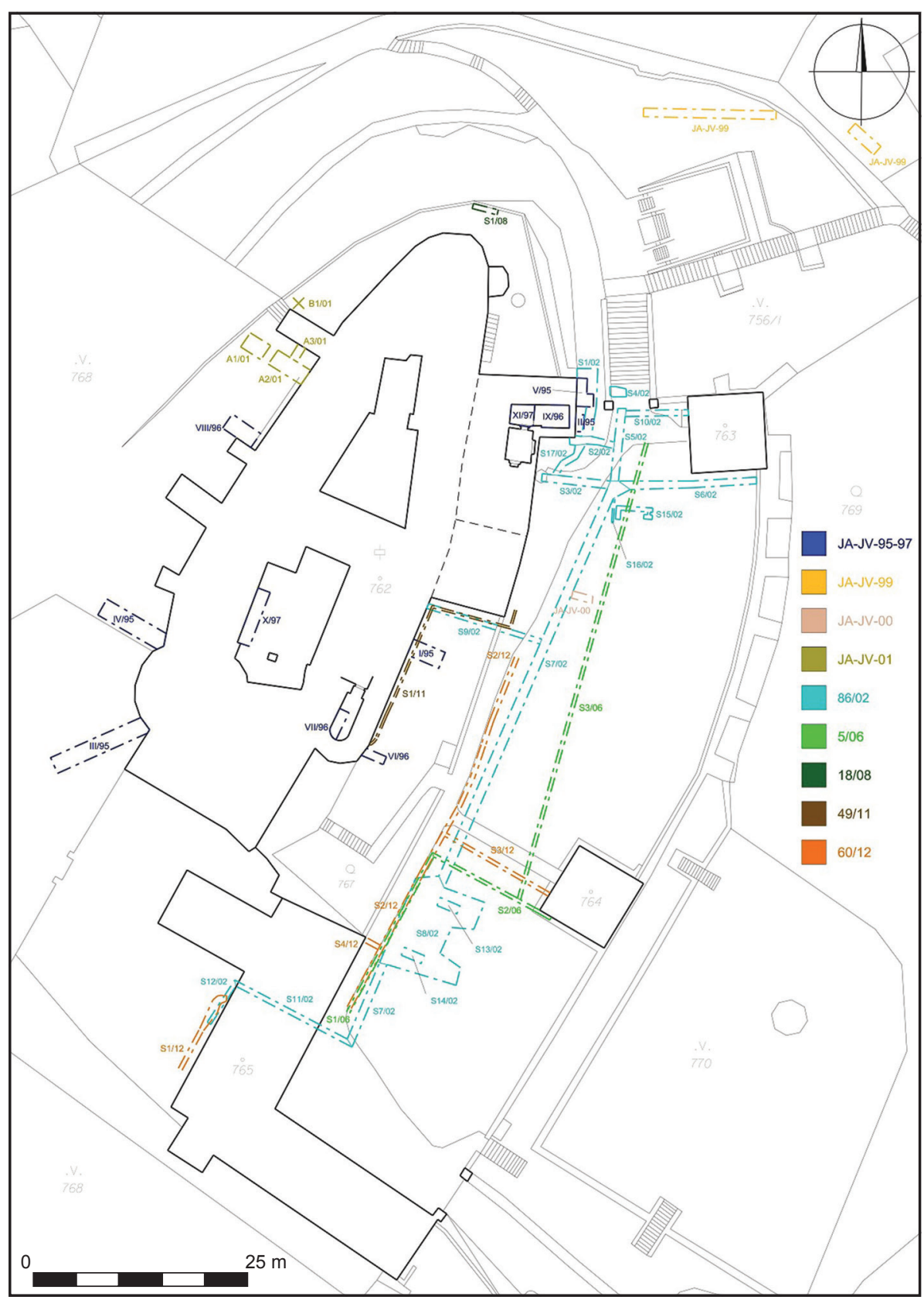

in thickness was unearthed, out of which further walls ran in an easterly direction (Kaiser, Šlézar 2007). It formed part of a building with the longer axis oriented in a north-south direction and had been most likely connected to the stone corner from the $14^{\text {th }}$ century, documented in 2002. Another stone wall discovered probably formed part of a cellar. It was unearthed in the eastern vicinity of the castle, stretching over 11 metres in length (Figure 7). Its eastern face ran in a $\mathrm{N}-\mathrm{S}$ direction and two further walls, $5.6 \mathrm{~m}$ apart, had been connected to it perpendicularly. The northern one was $2.2 \mathrm{~m}$, the southern one 1.5 metres, wide. A stone wall $0.9 \mathrm{~m}$ wide and at least $2 \mathrm{~m}$ long, bound by a limey mortar, was also identified in the farmyard. Just a Modern Age set of layers was identified in its vicinity (Faltýnek 2013).

\section{Methods}

In 2013, geophysical prospecting was carried out in both the small courtyard in the lower part of the castle and the eastern glacis. Both ground penetrating radar (GPR) and electric resistivity tomography (ERT) were used, specifically a SIR3000 GPR device (GSSI Inc., USA) with an antenna with a frequency of $400 \mathrm{MHz}$ and the geoelectric system ARES (Gf. Instruments, Czech Republic). The task was to identify the course of the High Middle Ages fortification ditch, the $15^{\text {th }}$ to $16^{\text {th }}$ century reconstructions of the castle fortification, and possibly other constructions in the eastern glacis. GPR measurement was realized in parallel lines spaced 0.5 metres apart, using a "zig-zag" pattern. Terrain disturbances to the 


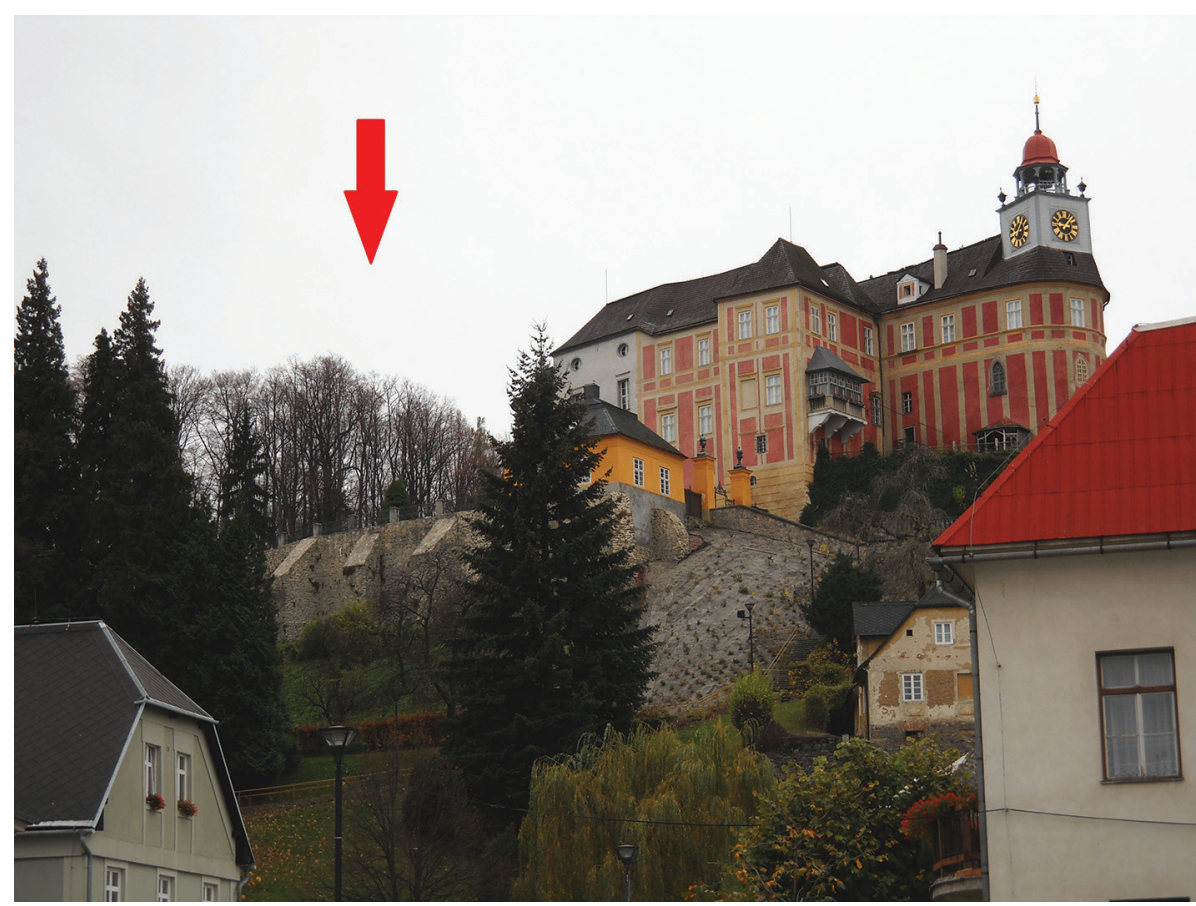

Figure 3. Javorník, Jánský Vrch, view from NE. The arrow marks the area of 3D scanning.

antenna were minimal as the small courtyard (Figure 7) is paved and the eastern glacis area is a shortly cut lawn. ERT was applied as straight line sectioning with the electrodes spaced at 0.5 metres. Length of the five realized sections varied between 15.5 and 39.5 metres.

Measurement results were processed with RADAN 6.5 (GPR) and RES2INV (Geotomo software, Malaysia) software. Both GPR and ERT methods are frequently used in geoarchaeological prospecting of medieval constructions and other stratigraphic units (e.g. Campana, Piro 2009; Tsokas et al. 2009).

We also focused on the flat area south of the castle (Figure 3). Behind the medieval ditch, the terrain rises steeply and turns into a plateau overlooking the entire castle.
This plateau, however, is dotted by terrain bumps. Already in the 1930s, two of these bumps were recorded in a drawing and identified as "Schanzen" (Figure 4; Anonymous 1934). Thus 3D laser scanning was applied to verify the presence and course of any fortification remnants. Results from the measurements made it possible to create a digital model of the terrain (Martínek 2014). The data were acquired by a private company through ground laser scanning, using the FARO FOCUS 3D scanner with a reach of 130 metres, a resolution of $<2 \mathrm{~mm}$ and scanning speed of 976,000 points per second. Each point on the surface was characterized by three coordinates and also by its colour, reflecting the intensity of the received signal. In this way, a cloud of $1,159,214,300$ points was acquired, referenced to 5 fixed

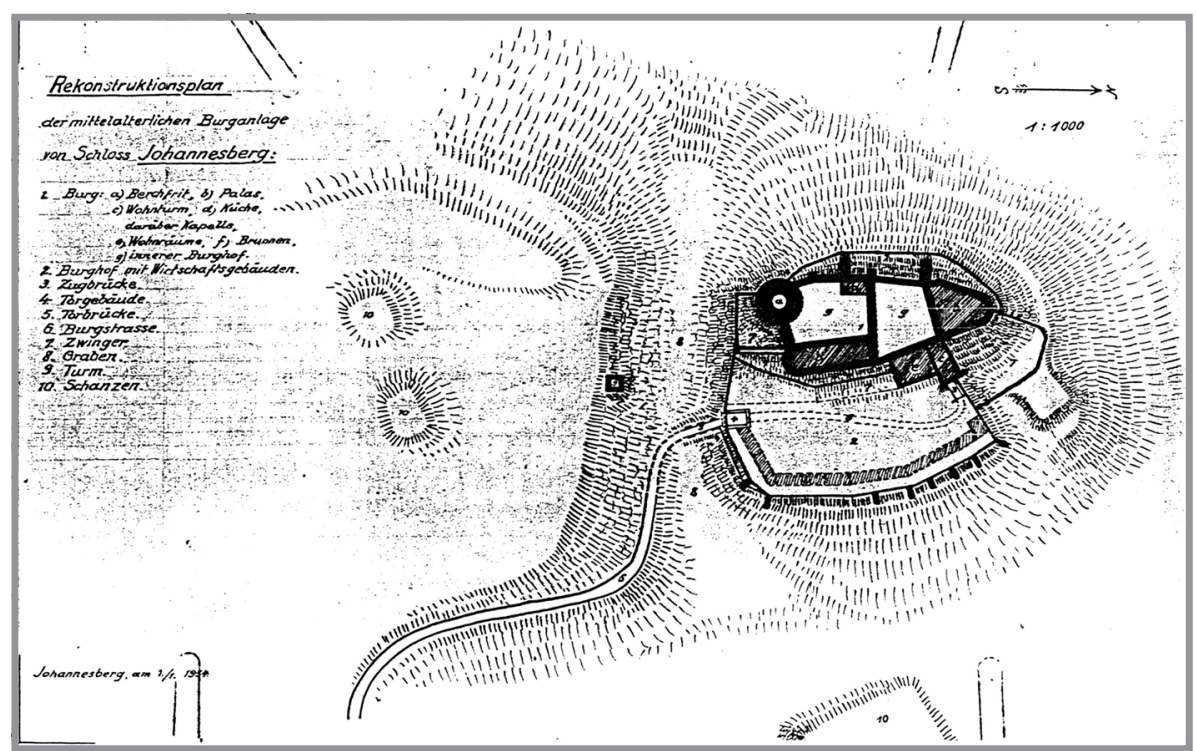

Figure 4. Reconstruction of the medieval castle area, 1934. 
Figure 5. Results of GPR measurement in the small courtyard (top) and the eastern glacis (bottom).
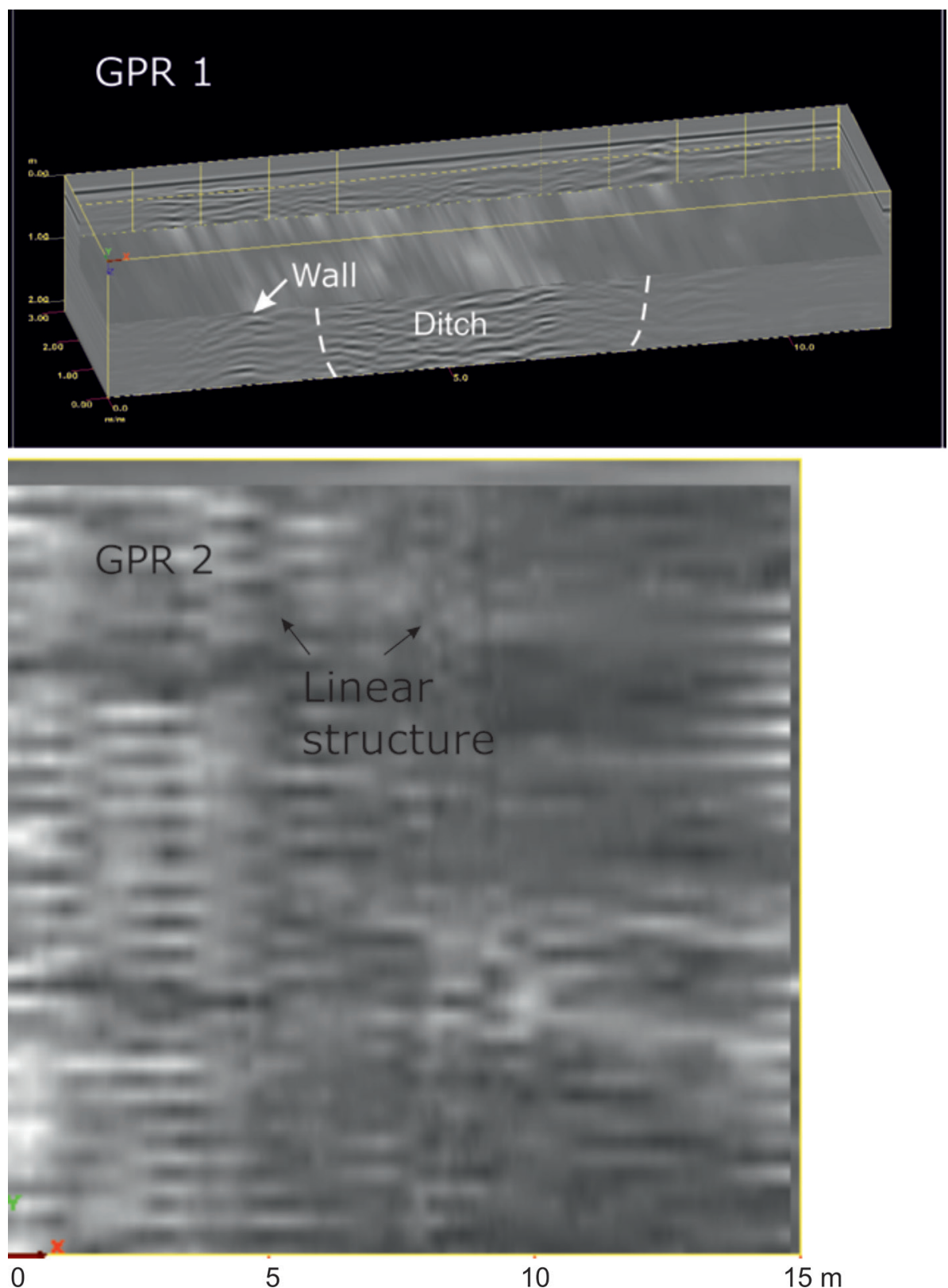

5
$15 \mathrm{~m}$ points situated around the measured area and thus located in the S-JTSK/BpV cartographic system. A digital elevation model was then calculated through interpolation using the ArcGIS 10.1 program (Esri inc., USA).

\section{Results}

\subsection{Geophysics}

Two areas were submitted to GPR measurement (Figure 5). The first one was the small courtyard where a rectangular GPR1 Probe 1 , the size of $12 \times 3 \mathrm{~m}$, was used. Two anomalies were identified here, the first one indicated by an intense ("wavy") microwave signal, the other by a significant concave anomaly. The second GPR measurement (GPR2), the size of $15 \times 15 \mathrm{~m}$, was made in the eastern glacis. What became evident here were two linear structures running in an approximately N-S direction and evidenced also in the ERT Section 4 (see below).

As for the ERT measurement, six sections (Sections 1-6) were made in the eastern glacis area (Figure 6), ranging in length from 15.5 to $39.5 \mathrm{~m}$. Each of them identified a number of subsurface anomalies, ranging in values from almost zero to about $700 \Omega \mathrm{m}$. The depth reached by this kind of ERT prospecting is dependent on the length of the section and ranged between 3.5 to $7.5 \mathrm{~m}$. In general, lower positioned layers and fills showed lower resistivity values, whereas units close to the surface were usually more resistive.

\subsection{Laser scanning}

The 3D laser scanning was suitable for the imaging of even the slightest terrain irregularities within the large areas. The images acquired through 3D laser scanning on the plateau south of the castle visualized two irregularly rectangular 

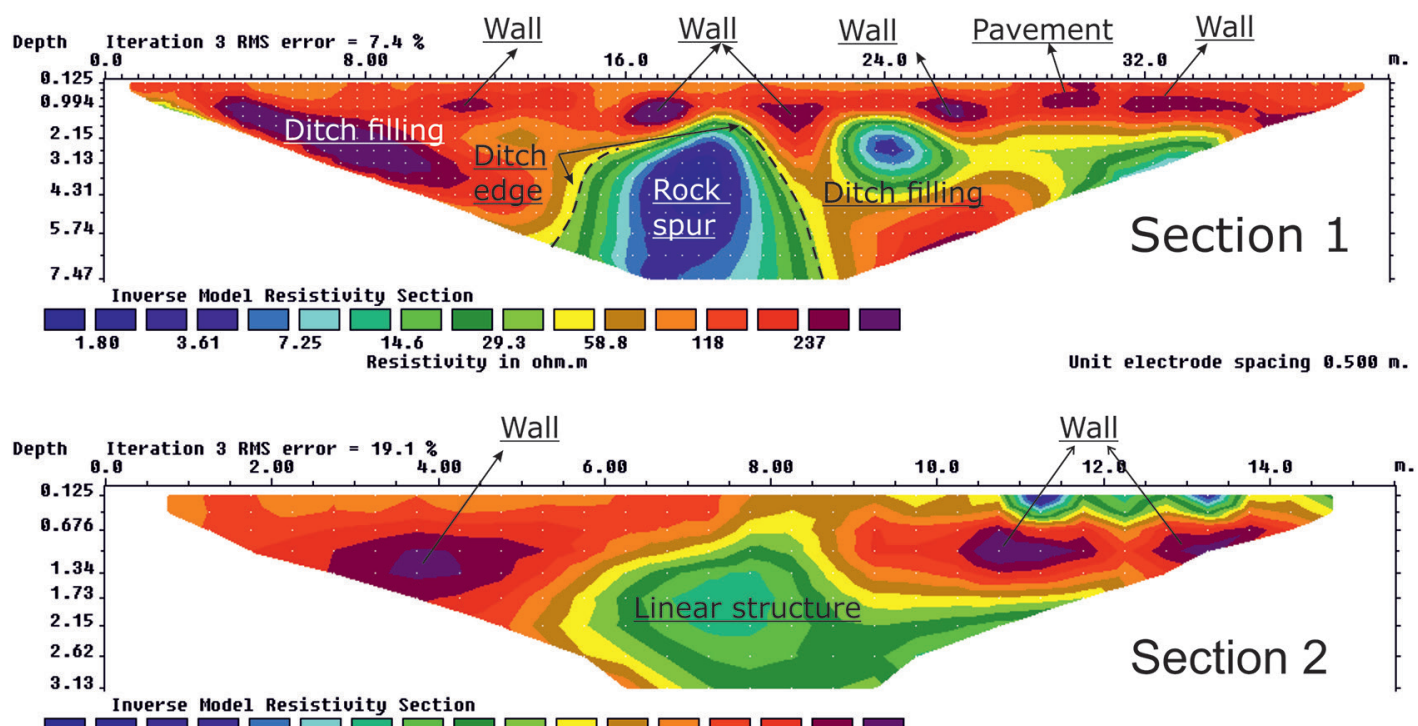

${ }_{6.84} \square_{11.2} \underset{18.4}{\square} \underset{38.2}{\square} \underset{49.5}{\square} \square_{81.2} \square_{133}^{\square} \square_{219} \square \square$

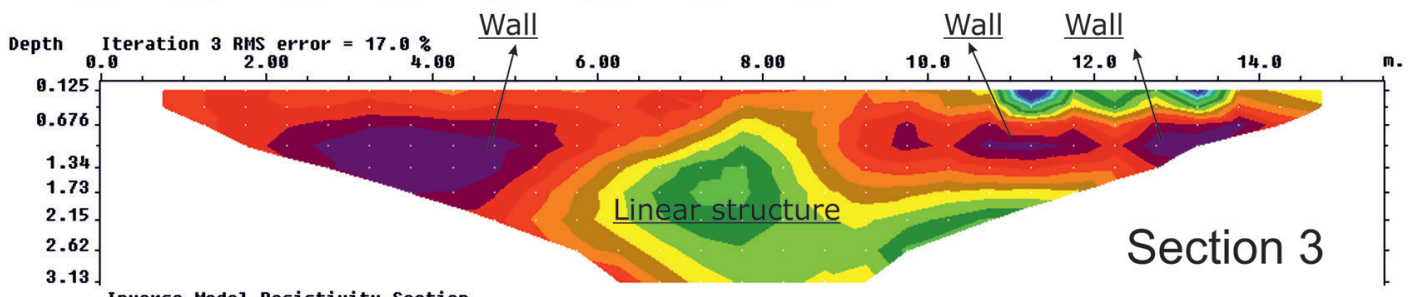

Inverse Model Resistivity Section

$6.21 \square_{9.95} \square_{15.9} \square_{25.5} \square_{48.9} \square_{65.4} \square \underset{105}{\square} \square_{168}$
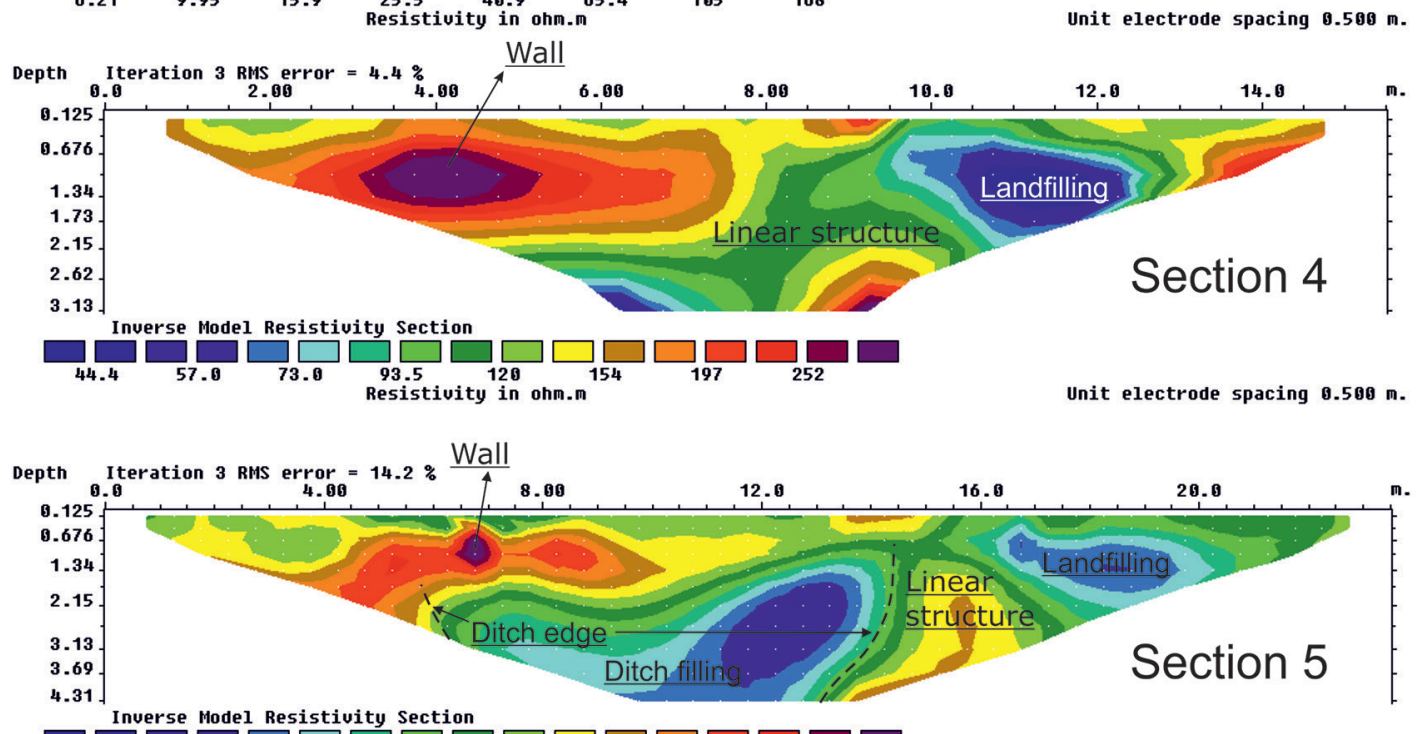

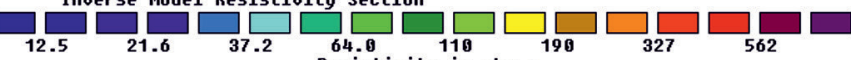

Unit electrode spacing $0.500 \mathrm{~m}$.

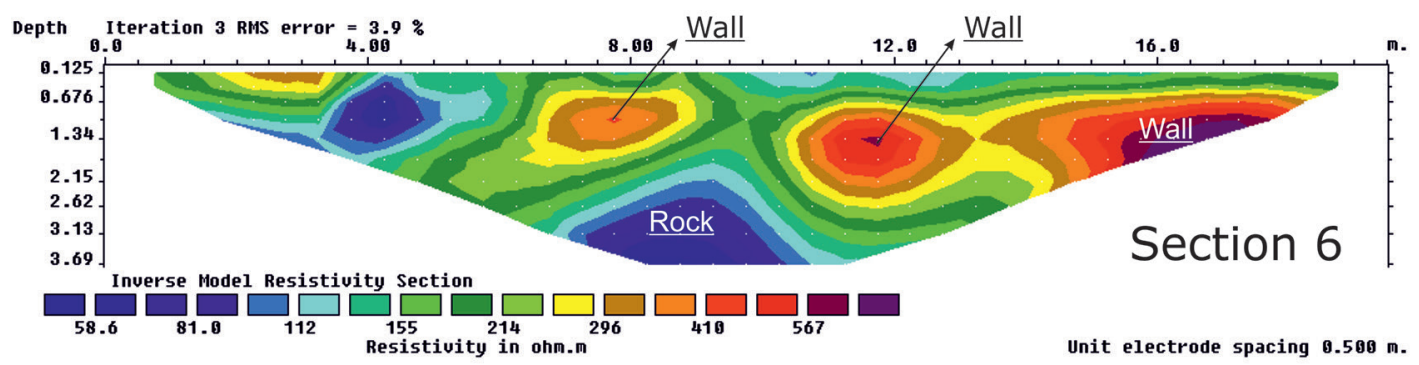

Figure 6. Six ERT sections executed in the eastern glacis and their interpretation. 
Figure 7. Plan of ERT and GPR measurements, course of supposed High Middle Ages fortification ditch, different parts of the castle mentioned in text, and structures unearthed by archaeological excavation

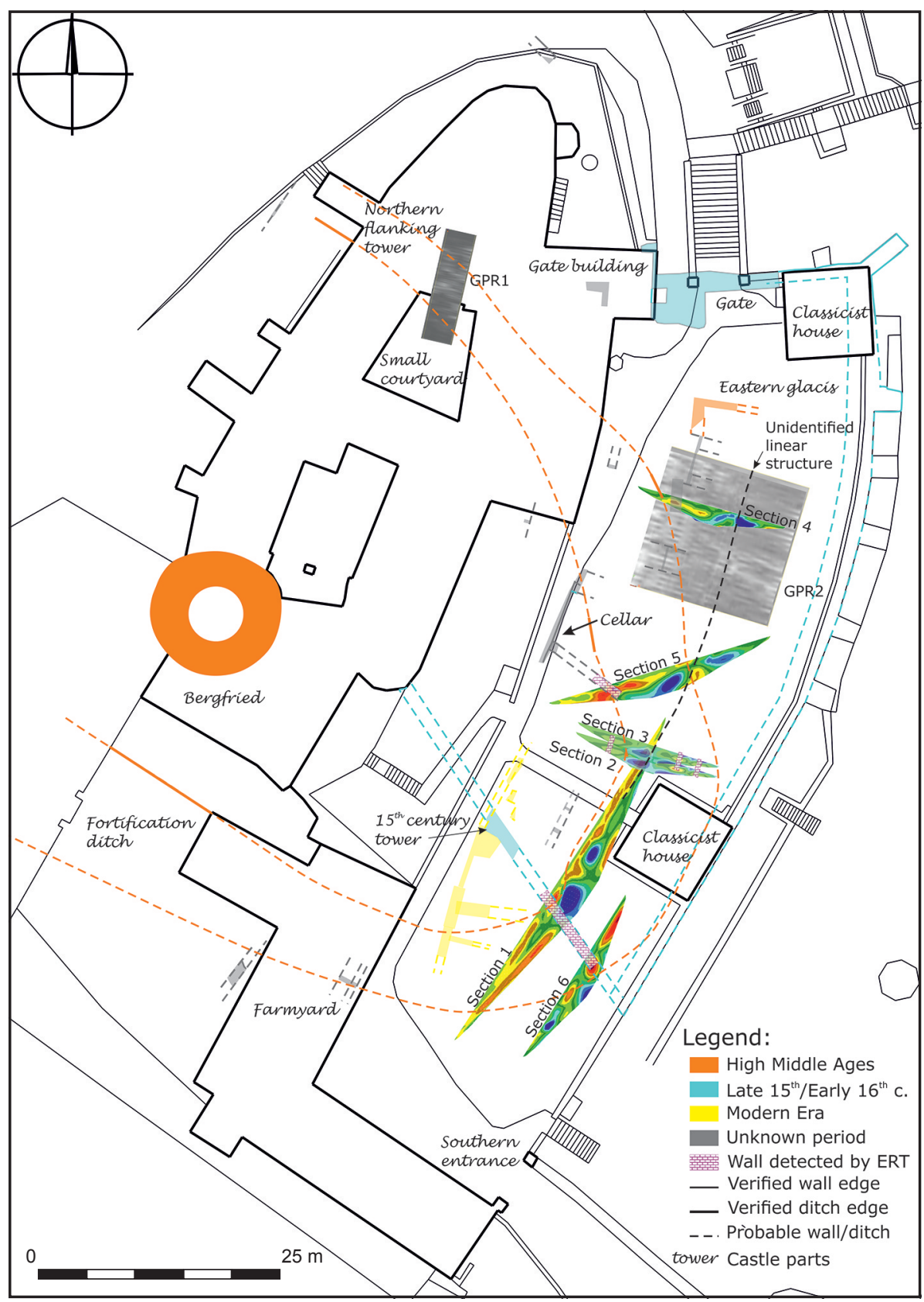

elevations the size of $12 \times 20$ and $10 \times 15 \mathrm{~m}$, about $25 \mathrm{~m}$ apart (Figures 8 and 9). Their situation answers to the drawing from 1934 (Figure 4). In contrast to that drawing, further terrain modifications became evident thanks to the laser scanning.

\section{Discussion}

The anomalies identified through GPR measurement in the small courtyard answer to a disturbed subsurface of intense radar signal in the southern part, possibly representing the filling of a ditch, whereas the concave-like signal (Figure 5) in the northern part probably represents a wall ( $c f$. Herz, Garisson 1998; Figure 8.10). The existence of High Middle Ages ditch in these parts was expected as its course had also been identified in the area of the flanking tower (Kouril 2009; Rychlý, Kolár 2002) and its continuation had been unearthed in the eastern glacis in the close vicinity of today's entrance (Šlézar 2003; Dehnerová, Šlézar 2013).

Two linear structures identified in the $15 \times 15 \mathrm{~m}$ GPR Probe 2 in the eastern glacis are of unknown function so that they can be classified just as "linear structures" (Figure 7). Their course does not answer to the medieval ditch, they are, however, parallel to the defensive wall from the $15^{\text {th }}$ or $16^{\text {th }}$ century. Whether they formed part of the defensive system or not is, as yet, unclear, as is their age. The eastern structure is more significant: as was also detected by the ERT measurement (see below).

In ERT sections, the anomalies can be broadly divided into four principal categories. The first is a low resistivity signal 


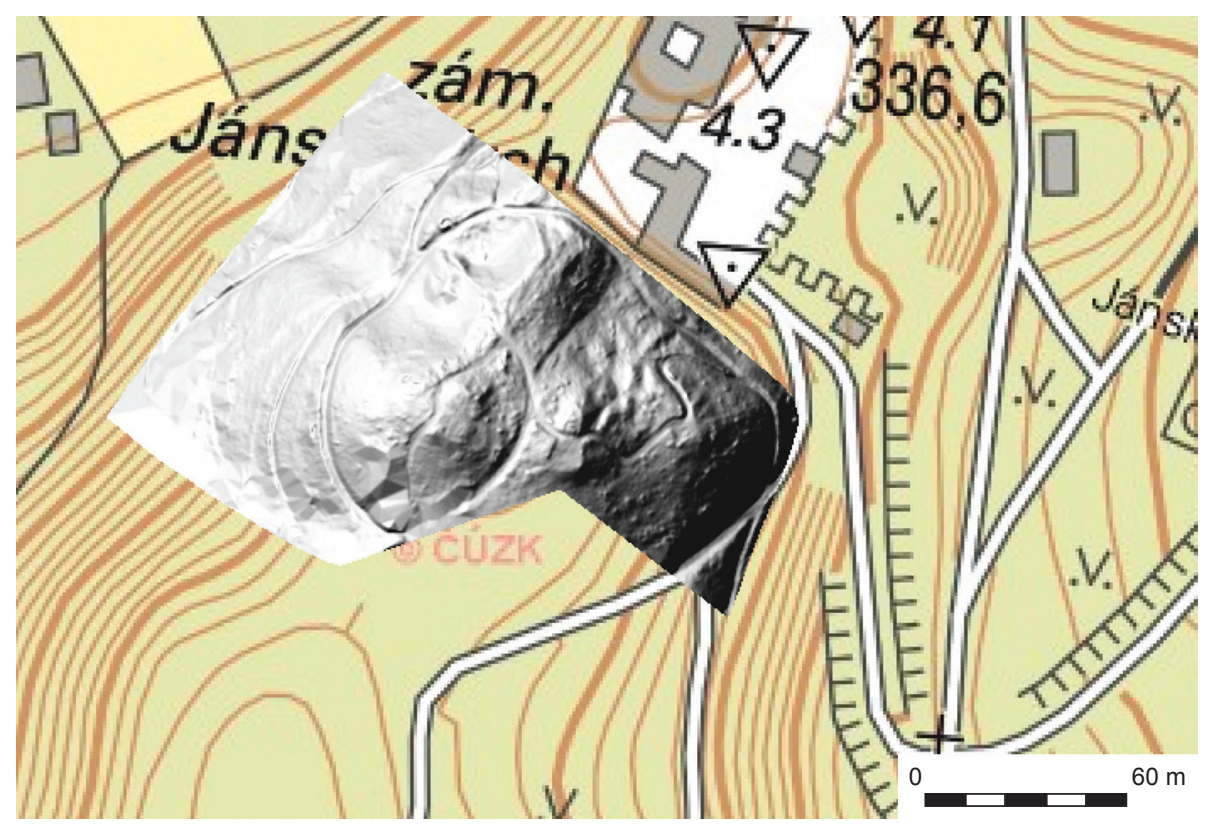

Figure 8. Shaded relief acquired by interpolation of 3D laser scanning. Angle of exposure: $315^{\circ}$; $\mathrm{Z}$ factor: 4 .

(0-80 $\Omega \mathrm{m})$, identified just in Section 1 and potentially in Section 6. It may be supposed that this might be a reflection from the local bedrock, as amphibolites are often rich in low-resistivity iron-rich minerals, although porosity may be also responsible for the low resistivity (e.g. Philpotts 2003; Milsom 2003). If the low-resistivity anomaly in Section 1 is indeed a rock spur, it must have been encircled by the High Middle Ages defensive ditch just in this place (Figure 7).

The second is a slightly higher resistivity anomaly, observed in Sections 2-5 (25-120 $\Omega \mathrm{m})$. It forms a kind of heap and can be related to one of the linear anomalies also identified in the GPR Probe 2. Its function is unclear. If it is of artificial origin, which seems probable, it must have reached at least a depth of $4.3 \mathrm{~m}$ (Figure 6, Section 5) so that a defensive function can be presumed.
In the course of terrain levelling later on, some heaping of low-resistivity (about $12-80 \Omega \mathrm{m}$ ) soil east of this structure took place as indicated by Sections 4 and 5. Finally, there are high-resistivity anomalies in practically all ERT sections, ranging between $200-800 \Omega \mathrm{m}$. These may be related to walls, and connected with both the buildings and Modern Age fortification lines. In Sections 1 and 6, a continuation of the $15^{\text {th }}-16^{\text {th }}$ century defensive wall, unearthed by archaeological excavation further to the west, was probably detected, and walls of buildings from the same period were recorded in Sections 4 and 5. Walls of unknown age or continuation were detected in Sections 2 and 3.

As for the High Middle Ages ditch, unearthed in places by earlier archaeological excavation, this was probably detected in Section 1 and 5. Its filling is low-resistive $(25-50 \Omega \mathrm{m})$

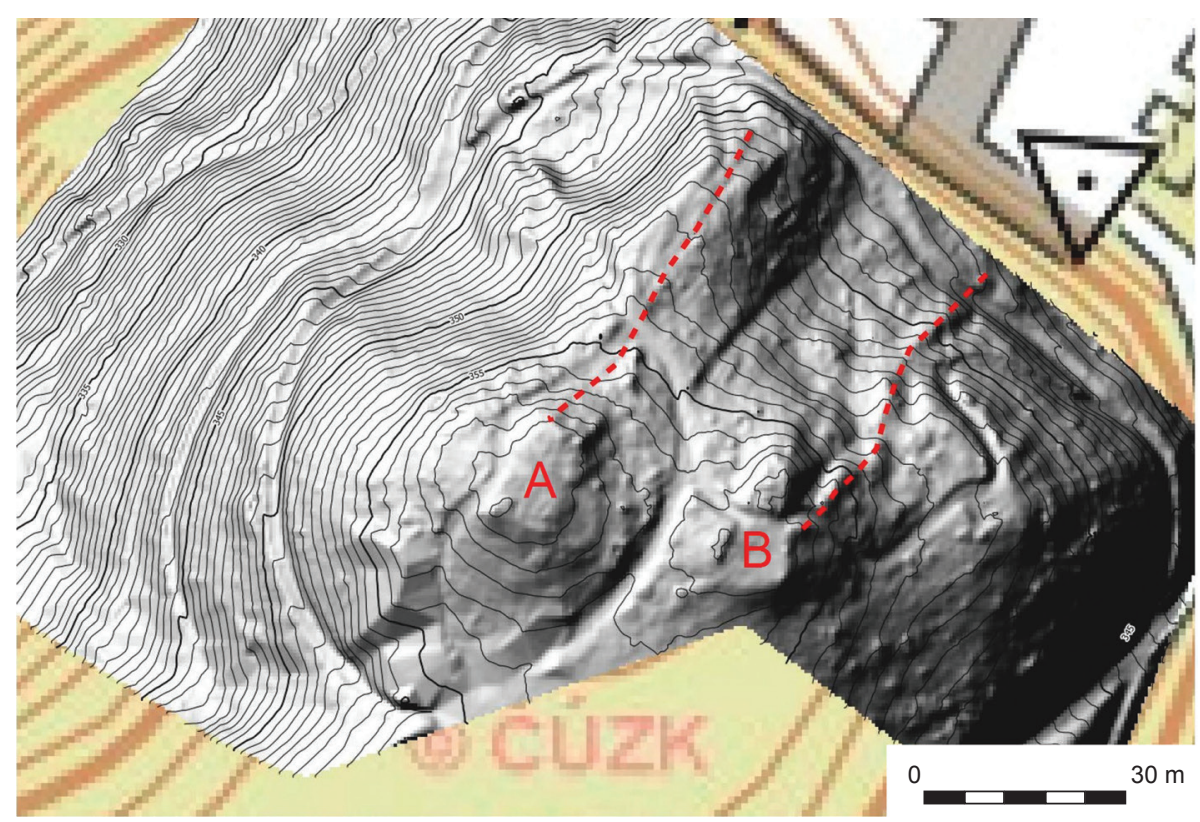

Figure 9. Interpolated image of elevations (A, B) and terrain remnants of a supposed light fortification south of the castle. Angle of exposure: $315^{\circ}$. 
in Section 5 but high-resistive in Section 1 (up to about $400 \Omega \mathrm{m}$ ) where it is probably formed by construction debris. This finding, however, should be verified in the future with ERT sectioning of a larger dimension or by archaeological excavation. Ditch filling was not detected in Sections 2-4 and 6 as it had been obliterated by younger landfills and constructions.

The 3D laser scanning of the terrain south of the castle (Figure 8) not only confirmed visual prospecting undertaken earlier but also made the shapes recorded in drawing in 1934 and in the contour mapping of 1991 more precise (Vozda 1991). Most of the recorded irregularities are likely park tracks and paths. More interesting are less pronounced terrain irregularities along the edge of the plateau, between the elevations and the northern edge of the plateau (Figure 9). These may represent remnants of a lighter fortification of the plateau. Even though the elevations are considered to be of medieval age in the reconstruction from 1934, it cannot be excluded that they are Modern Age structures originating from Romantic era modifications of the chateaux gardens (all above the eastern elevation; Figure 9:B). More probable, however, is that they are of medieval origin. Their form (including the lines of possible light fortification) and situation close to the ditch in front of the core of the castle may be related to fortification works. Historical records of the castle's history indicate the diocese castle was besieged between 1428 and 1434 by the Hussites. Archaeological excavation undertaken close to the northern flanking tower in 2001 demonstrated battle activities from around this period, most probably from the spring of 1428 (Kouril 2009). It is quite possible the plateau had been fortified by this time, forming either an advanced fortification of the castle or the siege camp of the Hussites. Archaeological excavation is required to confirm or disprove these possibilities.

\section{Conclusion}

The first phase of Javorník castle was constructed at the beginning of the $14^{\text {th }}$ century as a bergfried type with a curved fortification ditch. It was rebuilt in the $15^{\text {th }}$ and $16^{\text {th }}$ centuries together with the fortification system. In the Modern Age, new buildings appeared in the glacis, as indicated by contemporary vedutas. Both GPR and ERT measurements identified structures related to the mentioned construction phases. ERT Sections 1 and 5 probably detected the High Middle Ages fortification ditch, whereas virtually all sections detected building walls either of unknown age or dating from the $15^{\text {th }}$ to $16^{\text {th }}$ centuries. A linear structure, possibly a fortification line of unclear age, was also detected in ERT Sections 2-5 and GPR Probe 2. From a methodological point of view, the combination of these two methods proved itself effective.

Prospecting with 3D laser scanning identified several irregularities on the hill south of the castle. Two parallel lines south of two prominent elevations within the hill represent either an amplification of the medieval castle or a siege fortification related to the Hussite siege of Javorník in the spring of 1428 .

\section{Acknowledgements}

This article was written as part of the investigation "Archaeology 1.2, investigation of archaeological potential of selected historical areas and objects in the Czech Republic" supported financially by the conceptual development program (DKRVO) of the Ministry of Culture. Our thanks are due to Milan Rychlý from the Regional Museum in Jeseník and Kateřina Danielová from the Cultural Heritage Service in Kroměříž, the castle manager.

\section{References}

ANONYMOUS 1934: Rekonstruktionsplan der mittelalterlichen Burganlage von Schloss Johannesberg. Copy, nr. SHPP-JV/26. In: Kubeša, P. 1996: Revize parků okresu Jeseník 9. Javorník - zámecký park. MS, nr. 3170. Deposited: Library of the National Heritage Institute, Regional Office in Olomouc.

BRACHTL, Z. 1998: Zjišt’ovací výzkum na zámku Jánský Vrch v Javorníku, okres Jeseník. Badania archeologizcne na Górnym Śląsu i ziemiach pogranicznych w 1995 roku, 134-136.

BRACHTL, Z. 2000: Druhá etapa zjišt’ovacího výzkumu na zámku v Javorníku, okres Jeseník. Badania archeologizcne na Górnym Śląsku i ziemiach pogranicznych w 1996 roku, 159-161.

BRACHTL, Z., DOHNAL, J. 1992: Středověké tvrziště v Javorníku-Vsi, okr. Šumperk. Výsledky archeologického a geofyzikálního průzkumu. Vlastivědný věstnik moravský XLIV/4, 496.

CAMPANA, S., PIRO, S. (Eds.) 2009: Seeing the unseen: Geophysics and landscape archaeology. CRC Press, London.

DEHNEROVÁ, H., ŠLÉZAR, P. 2013: Archeologický výzkum na východním předhradí státního zámku Jánský Vrch. Časopis Slezského muzea, série B, 62/2013, 115-128.

FALTÝNEK, K. 2013: Javorník (okr. Jeseník). Zámek Jánský vrch. Přehled výzkumu 54, 198-199.

HERZ, N., GARRISON, E. G. 1998: Geological methods for archeology. Oxford University Press, New York-Oxford.

KAISER, L., ŠLÉZAR, P. 2007: Javorník (k. ú. Javorník-město, okr. Jeseník). Zámek Jánský Vrch, parc. č. 762. Přehled výzkumů 48, 468

KOUŘIL, P. 2009: Hrad Javorník: březen 1428 - září 1434 (příspěvek k poznání hmotné kultury doby husitské ve Slezsku). Časopis Slezského zemského muzea, série B, 58/2009, 221-235.

KOUŘIL, P., PRIX, D., WIHODA, M. 2000: Hrady českého Slezska. Archeologický ústav Akademie věd České republiky, Brno.

MARTÍNEK, M. 2014: Laserové skenování SZ Jánský Vrch. MS. Report, nr. D-975. Deposited: Library of the National Heritage Institute, Regional Office in Olomouc.

MILSOM, J. 2003: Field geophysics. Third edition, Wiley, London.

PHILPOTTS, A. R. 2003: Igneous and metamorphic rocks. Waveland Press, Illinois.

RYCHLÝ, M., KOLÁŘ, F. 2002: Výsledky archeologického výzkumu na Jánském Vrchu. Jesenicko. Vlastivědný sbornik, sv. 3, 44-46.

ŠLÉZAR, P. 2003: Javorník (okr. Jeseník). Zámek Jánský Vrch. Přehled výzkumů 44, 254-255.

TSOKAS, G. N., TSOURLOS, P. I., PAPADOPOULOS, N. 2009: Electrical resistivity topography: A flexible technique in solving problems of archaeological research. In: Campana, S., Piro, S. (Eds.): Seeing the unseen: geophysics and landscape archaeology. London, 83-104.

VÍTEK, T. 2010: Výsledky stavebně-historických průzkumů fasád zámku Jánský Vrch (okres Jeseník). Zprávy památkové péče 70/3, 209-218. 
VOZDA, J. 1991: Javorník, zámek Jánský Vrch - zámecký park. Výškopisné a polohopisné zaměření 1991. M 1:500. Nr. 91026; M0018374. MS.

Deposited: Library of the National Heritage Institute, Regional Office in Olomouc.
ŽÁČEK, V. 1995: Geologická mapa ČR, 1:50 000, list 14-22: Jeseník. Česká geologická služba 